\title{
The effect of tilapia Oreochromis niloticus addition on the sediment of brackish low-salinity ponds to white shrimp Penaeus vannamei farming system during the wet and dry season
}

\author{
Jorge Juárez-Rosales ${ }^{1}$, Alma D. Román-Gutiérrez ${ }^{1}$, Elena M. Otazo-Sánchez ${ }^{1}$, Griselda Pulido-Flores ${ }^{1}$, \\ Héctor M. Esparza-Leal ${ }^{2}$, Eugenio A. Aragón-Noriega ${ }^{3}$ \& Alireza Seidavi ${ }^{4}$ \\ ${ }^{1}$ Instituto de Ciencias Básicas e Ingeniería, Área Académica de Química, Posgrado en Ciencias Ambientales \\ Universidad Autónoma del Estado de Hidalgo, Pachuca, Hidalgo, México \\ ${ }^{2}$ Instituto Politécnico Nacional, Centro Interdisciplinario de Investigación para el Desarrollo \\ Integral Regional Unidad Sinaloa, Guasave, Sinaloa, México \\ ${ }^{3}$ Centro de Investigaciones Biológicas del Noroeste S.C., Guaymas, Sonora, México \\ ${ }^{4}$ Islamic Azad University, Rasht Branch, Rasht, Iran \\ Corresponding author: Alma D. Román-Gutiérrez (aroman@uaeh.edu.mx)
}

\begin{abstract}
The present study was carried out to determine the effect of tilapia Oreochromis niloticus on the physical and chemical sediment parameters on an earthen pond in monoculture (shrimp Penaeus vannamei) and co-culture (tilapia-shrimp) during the dry and wet seasons in a commercial farm during the period from midSeptember to end-December 2017 and February to mid-May 2018. Chemical and physical analyses were realized on sediment samples from brackish water ponds representing shrimp farms in San Blas Nayarit, Mexico. Concentrations of organic carbon, nitrogen, potassium, magnesium and calcium were higher in co-culture ponds, and there was a tendency to a higher concentration of phosphorus and sodium in the sediment of monoculture ponds. The texture of the ponds showed a tendency in the dry season to increase the percentage of clay in coculture due to the effect of bioturbation caused by tilapia. There was no evidence of poor development of sediment quality in any treatment. It was found that tilapia was a factor that affected sediment quality, differences in growth between shrimp monoculture and tilapia-shrimp co-culture can be explained, at least in part, by differences in their sediment.
\end{abstract}

Keywords: Oreochromis niloticus; Penaeus vannamei; sediment; co-culture; brackish pond

\section{INTRODUCTION}

The addition of tilapia to shrimp ponds has been used to improve water and sediment quality and shrimp production, compared to shrimp monoculture (Fitzsimmons \& Shahkar, 2017). Tilapia has been cultivated with a variety of fish and crustaceans under co-culture conditions mainly to improve production and have better environmental control of the farming system (Milstein \& Hernández, 2017). The co-culture of tilapia with white shrimp Penaeus vannamei, has been shown to improve production and nutrient utilization in relation to shrimp monoculture, obtaining a better profitability and less environmental contamination (Sun et al., 2011; Bessa et al., 2012; Hernández-
Barraza et al., 2013; Fitzsimmons \& Shahkar, 2017; López-Gómez et al., 2017). It encourages the development of bacterial communities, fungi, algae and bioflocs of the native biota of the shrimp where the coculture is carried out (Fitzsimmons \& Shahkar, 2017), as in brackish low-salinity ponds. In the last years the co-culture of tilapia-shrimp has had a greater boom in small commercial farms of shrimp culture $P$. vannamei in Latin America among which are Brazil, Peru, Ecuador, Honduras and Mexico mainly, because it has been found that this culture strategy reduces diseases such as that caused by white spot shrimp virus, Vibrio harveyi and $V$. parahaemolyticus (Rodríguez-Grimón, 2003; Cruz et al., 2008; Tran et al., 2014). In the northwest of Mexico, most shrimp farms use the semi- 
intensive system in earthen ponds, where the southern Gulf of California farms are small 1 to 50 ha (PoncePalafox et al., 2011), where some follow the strategy of simultaneous polyculture system (tilapia and shrimp are grown together in a pond), which is common in other parts of the world (Fitzsimmons \& Shahkar, 2017).

Studies on tilapia-shrimp co-culture have been carried focused on the effect upon water quality (Alam et al., 2008; Brito et al., 2017), feeding (Jatobá et al., 2011), density (Candido et al., 2005), growth performance (Hernández-Barraza et al., 2012), production (Wang \& Lu, 2016), diseases (Dash et al., 2017) and profitability (Muangkeow et al., 2007). However, studies on the effects on soil-sediment are scarce, although it has been determined that conditions at the bottom of the pond have a strong influence on water quality and the production of shrimp (Sonnenholzner \& Boyd, 2000).

In the sediment, shrimp spend the majority of the culture at the water-sediment interface, so a change in the sediment has direct effects on the shrimp (FAO, 2013), as well as the risk of contracting a bacterial disease (Nimrat et al., 2008). The conditions of sediment and water quality in shrimp farming earthen ponds determine their health and the success of the culture (Saraswathy et al., 2019). In this type of pond, sediment is formed on the ground composed mainly of a higher concentration of organic carbon originated from plankton, feces, balanced feed and fertilizer (Munsiri et al., 1995). What causes the nitrogen and phosphorus compounds are a higher concentration in the sediment than in the water column (Yang et al., 2019). It has been found that within the first $4 \mathrm{~cm}$ depth is the zone of the sediment where nitrogen and phosphorus are released and transported (Cheng et al., 2014) and where the effect of tilapia of omnivoresdetritivores habits on the sediment can be better detected. There are many studies on water and sediment quality of Oreochromis niloticus (Ram et al., 1982; Avnimelec et al., 1999; Adámek \& Maršálek, 2013; Fan et al., 2017; Omofunmi et al., 2016) and $L$. vannamei (Nimrat et al., 2008; Joyni et al., 2011; Van Duc et al., 2018; Yang et al., 2019) in ponds. However, there are few studies on the effect of tilapia-shrimp coculture in rustic ponds at different times of the year. Therefore, this study aimed to determine the effect of tilapia $O$. niloticus on the physical and chemical soil parameters on an earthen pond in mono and co-culture with white shrimp during the dry season (concentration conditions) and rainfall season (dilution conditions) in a commercial farm.

\section{MATERIALS AND METHODS}

\section{Study area}

The experiment was carried out at Chiripa, San Blas Nayarit, northwest coast of Mexico (21 ${ }^{\circ} 37^{\prime} 34.53^{\prime \prime} \mathrm{N}$, $\left.105^{\circ} 18^{\prime} 16.31^{\prime \prime} \mathrm{W}\right)$. The mean temperature of the environment was from $22-26^{\circ} \mathrm{C}$ (García, 2004). The earthen ponds have a surface area from 2.75 to 3.2 ha and $1.2 \mathrm{~m}$ deep. The ponds use water from a canal with salinity from 8.5 to 18.4 , depending on the time of year.

\section{Experimental animals}

Post-larval ( $\left.\mathrm{PL}_{15}\right)$ white shrimp (Penaeus vannamei) mean initial weight $=0.001 \pm 0.001 \mathrm{~g}$ were bought from a commercial hatchery, located in the Bay of Matanchen, municipality of San Blas, Nayarit, called "Acuacultura Integral, S.A. de CV." All the tilapia (5.0 $\pm 0.6 \mathrm{~g}$ ) were transported from fingerling commercial hatchery "Genetilapia SA de CV," located at Rosario Sinaloa, Mexico.

\section{Experimental design}

Two trials were carried out using a completely randomized design consisting of two treatments (wet and dry season) with three replications (ponds) for each. The first trial takes 106 days of mid-September to endDecember 2017 (wet season), and the second trial took the same time as the first and was of February to midMay 2018 (dry season). Treatments were shrimp monoculture wet season (SMW) and dry season (SMD) and tilapia-shrimp co-culture wet season (TSW) and dry season (TSD). Shrimp were stocked $\left(10\right.$ ind $\left.\mathrm{m}^{-2}\right)$ in monoculture ponds for all treatments; tilapia $\left(4\right.$ ind $\left.\mathrm{m}^{-2}\right)$ and shrimp (10 ind $\mathrm{m}^{-2}$ ) were stocked in co-culture ponds. First, the shrimp were stocked, and then the tilapia was added seven days later directly in each of the ponds, in all cases. The shrimp and tilapia in each earthen pond were collected from a harvesting pit. The tilapia and shrimp were fed four times a day (07:00, 11:00, 15:00 and 19:00 h); commercial pellets for shrimp feed brand "Paymar", with 40-20\% (initialfinal) and 10-20\% (initial-final) protein and lipids, respectively, were used. The ponds were initially fertilized 10 days before shrimp and tilapia stocking with NutriLake- $\mathrm{P}^{\circledR}$ commercial fertilizer $\left(5 \mathrm{~kg} \mathrm{ha}^{-1}\right.$ in each pond) for the growth of natural food organisms.

\section{Sediment analysis}

A kilogram of soil samples was collected from each tank at the initial and the end of the culture. In each pond, salinity (potential meter) and $\mathrm{pH}$ (Jackson, 1973, method) were determined. Organic matter (OM) was measured according to the procedures described in Rayment \& Higginson (1992). Kjeldahl nitrogen was measured to determine total organic nitrogen (TN) in 
Table 1. Sediment variables in monoculture (shrimp Penaeus vannamei) and co-culture system (tilapia Oreochromis niloticus/shrimp) in water indoor pond water (IPW) during the wet season for 106 days. Values in each row with different superscript letters indicate significant differences between groups $(P<0.05)$. SMW: Shrimp monoculture wet season, TSW: Tilapia-shrimp co-culture wet season.

\begin{tabular}{|c|c|c|c|c|}
\hline \multirow{2}{*}{ Parameter/Treatment } & \multicolumn{2}{|c|}{ Initial sediment } & \multicolumn{2}{|c|}{ Final sediment } \\
\hline & SMW & TSW & SMW & TSW \\
\hline $\mathrm{OM}(\%)$ & $4.50 \pm 2.10^{\mathrm{b}}$ & $5.30 \pm 2.10^{\mathrm{b}}$ & $6.30 \pm 1.80^{\mathrm{a}}$ & $8.70 \pm 1.60^{\mathrm{a}}$ \\
\hline $\mathrm{TN}\left(\mathrm{kg} \mathrm{ha}^{-1}\right)$ & $156.00 \pm 42.20^{\mathrm{d}}$ & $312.00 \pm 42.30^{\mathrm{b}}$ & $275.00 \pm 32.70^{c}$ & $405.00 \pm 32.90^{\mathrm{a}}$ \\
\hline $\mathrm{TP}\left(\mathrm{mg} \mathrm{kg}^{-1}\right)$ & $1,023.00 \pm 345.10^{\mathrm{b}}$ & $1,215.00 \pm 341.20^{b}$ & $1,653.70 \pm 170.10^{a}$ & $1,456.00 \pm 173.20^{b}$ \\
\hline $\mathrm{K}\left(\mathrm{mg} \mathrm{kg}^{-1}\right)$ & $32.10 \pm 7.00^{\mathrm{a}}$ & $45.60 \pm 13.50^{\mathrm{b}}$ & $39.40 \pm 7.20^{b}$ & $49.30 \pm 13.90^{\mathrm{a}}$ \\
\hline $\mathrm{Mg}\left(\mathrm{mg} \mathrm{kg}^{-1}\right)$ & $1,786.00 \pm 176.60^{\mathrm{b}}$ & $1,254.00 \pm 252.40^{c}$ & $2,036.00 \pm 175.20^{\mathrm{a}}$ & $2,038.00 \pm 259.10^{\mathrm{a}}$ \\
\hline $\mathrm{Ca}\left(\mathrm{mg} \mathrm{kg}^{-1}\right)$ & $1.60 \pm 0.51^{\mathrm{b}}$ & $2.30 \pm 0.31^{\mathrm{a}}$ & $2.40 \pm 0.52^{\mathrm{a}}$ & $2.90 \pm 0.29^{\mathrm{a}}$ \\
\hline $\mathrm{pH}$ & $7.80 \pm 0.14^{\mathrm{a}}$ & $7.50 \pm 0.02^{\mathrm{a}}$ & $7.60 \pm 0.16^{a}$ & $7.60 \pm 0.01^{\mathrm{a}}$ \\
\hline $\mathrm{Na}\left(\mathrm{mg} \mathrm{kg}^{-1}\right)$ & $1,456.00 \pm 394.50^{\mathrm{b}}$ & $1,136.00 \pm 528.40^{\mathrm{b}}$ & $2,064.00 \pm 391.20^{\mathrm{a}}$ & $2,039.00 \pm 516.30^{\mathrm{a}}$ \\
\hline SA $(\%)$ & $11.30 \pm 0.27^{\mathrm{b}}$ & $14.50 \pm 0.60^{\mathrm{a}}$ & $10.50 \pm 0.29^{\mathrm{a}}$ & $10.50 \pm 0.20^{\mathrm{a}}$ \\
\hline SI $(\%)$ & $18.30 \pm 7.10^{\mathrm{b}}$ & $32.10 \pm 2.70^{\mathrm{a}}$ & $28.40 \pm 7.30^{\mathrm{a}}$ & $28.40 \pm 2.30^{\mathrm{a}}$ \\
\hline CL $(\%)$ & $70.40 \pm 6.70^{\mathrm{a}}$ & $53.40 \pm 4.40^{c}$ & $61.30 \pm 6.10^{b}$ & $61.10 \pm 4.10^{\mathrm{b}}$ \\
\hline
\end{tabular}

the soil according to the procedure described in Soil Survey Staff (2014). Total phosphorus (TP) was measured in soil extract obtained from perchloric digestion (Horwitz, 2002). Macronutrients such as calcium $(\mathrm{Ca})$, magnesium $(\mathrm{Mg})$, sodium $(\mathrm{Na})$ and potassium $(\mathrm{K})$ were analyzed by extraction with ammonium acetate $\mathrm{pH}=7$ modified (Woerner, 1989). A granulometry study was carried out according to Soil Survey Staff (1999) sieving the sediment sample and Pipette method (Day, 1965) was used to determine the following fractions: clay (CL) $(<2 \mu \mathrm{m})$, silt (SI) $(2-50$ $\mu \mathrm{m})$ and sand (SA) $(50-2000 \mu \mathrm{m})$. Gravel fractions $(>2$ $\mathrm{mm})$ were not detected. Other analyses were carried out on the fine fractions of the sediment $(<2 \mathrm{~mm})$ following the method used by Aldama-Rojas et al. (2011).

\section{Statistical analysis}

The results of sediment variables were checked using Levene's test for homogeneity of variances and Shapiro-Wilk's test for normality (Sokal \& Rolhf, 2012). Differences between treatments were compared using one-way analysis of variance (ANOVA), and Tukey's test was applied to determine which treatments differed significantly. To determine the most important sediment parameters and the multivariate effects on the sampling sites, a correlation matrix, principal components, and discriminant analysis were performed. Data were analyzed using Statistica for Windows (version 5.5 Inc., USA).

\section{RESULTS}

In the wet season, no significant differences $(P>0.05)$ in $\mathrm{pH}$ were found between all sampling stations (Table 1). There were significant differences $(P<0.05)$ between the initial concentrations of $\mathrm{OM}, \mathrm{TN}, \mathrm{TP}, \mathrm{Mg}$ and $\mathrm{Na}$ and those recorded at the end of the culture. The OM, $\mathrm{TP}, \mathrm{Mg}, \mathrm{Ca}, \mathrm{Na}, \mathrm{SA}, \mathrm{SI}$ and $\mathrm{CL}$ concentrations were similar in the monoculture and co-culture system at the end of the experiment. Only significant differences $(P$ $<0.05$ ) were found in $\mathrm{TN}$ and $\mathrm{K}$ in the two strategies used, higher $\mathrm{TN}$ concentration and lower $\mathrm{K}$ in coculture.

In the dry season, there were significant differences between the initial concentrations of $\mathrm{OM}, \mathrm{TN}, \mathrm{K}, \mathrm{Mg}$, $\mathrm{Ca}, \mathrm{pH}, \mathrm{Na}, \mathrm{SA}, \mathrm{SI}$ and $\mathrm{CL}$ and those recorded at the end of the culture (Table 2).

The OM, TN, K, Mg, Ca, pH, Na, SA, SI and CL concentrations were similar in the monoculture and coculture system at the end of the experiment. Only significant differences were found in TP in the two strategies used, higher TP concentration in monoculture. There was a tendency for the sediment of the co-culture system to have a higher percentage of clay.

In the wet season, the most significant proportional correlations were OM-TN, TP-pH-SI, K-Mg-Na-CL and $\mathrm{Mg}-\mathrm{Na}$, and inversely proportional between SA-SI. (Table 3). In the dry season, the most significant proportionally correlations were OM-TN, TP-pH, K$\mathrm{Mg}$ and $\mathrm{pH}-\mathrm{Na}$ (Table 4).

Two groups of sediment variables were found, one related to the dynamics of phosphorus and nitrogen, and the other to changes in sediment composition with OM, $\mathrm{K}, \mathrm{Ca}$ and $\mathrm{pH}$ through cluster analysis (Fig. 1a). The principal components analysis showed that four processes occur in the sediment, such as the SA-SI, TN-OM, $\mathrm{pH}$, and TP relationships (Fig. 1b).

The cluster analysis of the sampling stations showed that there is a significant difference $(P<0.05)$ between 
Table 2. Sediment variables in monoculture (shrimp) and co-culture system (tilapia/shrimp) in water indoor pond water (IPW) during the dry season for 106 days. Values in each row with different superscript letters indicate significant differences between groups $(P<0.05)$. SMD: Shrimp monoculture dry season, TSD: Tilapia-shrimp co-culture dry season. OM: organic matter, TN: organic nitrogen, TP: total phosphorus, $\mathrm{K}$ : potassium, Mg: magnesium, CA: calcium, pH: acidity, NA: sodium, SA: sand, SI: silt, CL: clay.

\begin{tabular}{lrrrrr}
\hline \multirow{2}{*}{ Parameter/Treatment } & \multicolumn{2}{c}{ Initial sediment } & & \multicolumn{2}{c}{ Final sediment } \\
\cline { 2 - 3 } \cline { 5 - 6 } \cline { 5 - 6 } & \multicolumn{1}{c}{ SMD } & \multicolumn{1}{c}{ TSD } & \multicolumn{1}{c}{ SMD } & \multicolumn{1}{c}{ TSD } \\
\hline OM (\%) & $5.70 \pm 1.10^{\mathrm{b}}$ & $8.20 \pm 1.10^{\mathrm{b}}$ & & $10.00 \pm 1.80^{\mathrm{a}}$ & $12.00 \pm 1.60^{\mathrm{a}}$ \\
$\mathrm{TN}\left(\mathrm{kg} \mathrm{ha}^{-1}\right)$ & $260.00 \pm 2.20^{\mathrm{b}}$ & $278.00 \pm 2.30^{\mathrm{b}}$ & & $320.00 \pm 2.70^{\mathrm{a}}$ & $346.00 \pm 2.90^{\mathrm{a}}$ \\
$\mathrm{TP}\left(\mathrm{mg} \mathrm{kg}^{-1}\right)$ & $940.00 \pm 0.10^{\mathrm{b}}$ & $540.00 \pm 0.20^{\mathrm{c}}$ & & $1,255.20 \pm 0.10^{\mathrm{a}}$ & $792.70 \pm 0.20^{\mathrm{b}}$ \\
$\mathrm{K}\left(\mathrm{mg} \mathrm{kg}^{-1}\right)$ & $20.64 \pm 0.01^{\mathrm{b}}$ & $15.12 \pm 0.01^{\mathrm{c}}$ & & $29.92 \pm 0.02^{\mathrm{a}}$ & $32.74 \pm 0.01^{\mathrm{a}}$ \\
$\mathrm{Mg}\left(\mathrm{mg} \mathrm{kg}^{-1}\right)$ & $2,423.00 \pm 0.60^{\mathrm{b}}$ & $2,563.00 \pm 2.40^{\mathrm{b}}$ & & $3,292.00 \pm 1.00^{\mathrm{a}}$ & $3,891.00 \pm 1.10^{\mathrm{a}}$ \\
$\mathrm{Ca}\left(\mathrm{mg} \mathrm{kg}^{-1}\right)$ & $1.42 \pm 0.01^{\mathrm{b}}$ & $2.30 \pm 0.01^{\mathrm{a}}$ & & $2.10 \pm 0.02^{\mathrm{a}}$ & $2.40 \pm 0.01^{\mathrm{a}}$ \\
$\mathrm{pH}$ & $7.90 \pm 0.01^{\mathrm{a}}$ & $8.10 \pm 0.02^{\mathrm{a}}$ & & $7.50 \pm 0.06^{\mathrm{b}}$ & $7.30 \pm 0.01^{\mathrm{b}}$ \\
$\mathrm{Na}\left(\mathrm{mg} \mathrm{kg}^{-1}\right)$ & $3,036.00 \pm 0.40^{\mathrm{b}}$ & $2,530.00 \pm 0.40^{\mathrm{c}}$ & & $5,632.00 \pm 0.20^{\mathrm{a}}$ & $5,280.00 \pm 0.30^{\mathrm{a}}$ \\
SA $(\%)$ & $19.30 \pm 3.10^{\mathrm{b}}$ & $15.30 \pm 0.70^{\mathrm{b}}$ & & $24.90 \pm 0.20^{\mathrm{b}}$ & $24.90 \pm 0.20^{\mathrm{b}}$ \\
SI $(\%)$ & $35.30 \pm 0.20^{\mathrm{a}}$ & $39.30 \pm 0.60^{\mathrm{c}}$ & & $67.30 \pm 3.30^{\mathrm{a}}$ & $65.20 \pm 0.30^{\mathrm{a}}$ \\
$\mathrm{CL}(\%)$ & $45.40 \pm 4.70^{\mathrm{a}}$ & $45.40 \pm 2.40^{\mathrm{b}}$ & & $7.80 \pm 4.10^{\mathrm{c}}$ & $9.90 \pm 2.10^{\mathrm{c}}$ \\
\hline
\end{tabular}

Table 3. Correlations matrix sediment parameters in monoculture (shrimp) and co-culture system (tilapia/shrimp) in all treatments during the wet season for 106 days. Correlations values in bold are significant at $P<0.05$. OM: organic matter, TN: organic nitrogen, TP: total phosphorus, $\mathrm{K}$ : potassium, Mg: magnesium, CA: calcium, pH: acidity, NA: sodium, SA: sand, SI: silt, CL: clay.

\begin{tabular}{lrrrrrrrrrrr}
\hline Variable & OM & \multicolumn{1}{c}{ TN } & \multicolumn{1}{c}{ TP } & \multicolumn{1}{c}{ K } & MG & CA & PH & NA & SA & SI & CL \\
\hline OM & 1.00 & & & & & & & & & & \\
TN & $\mathbf{0 . 7 7}$ & 1.00 & & & & & & & & & \\
TP & 0.53 & 0.64 & 1.00 & & & & & & & & \\
K & 0.22 & -0.23 & -0.15 & 1.00 & & & & & & & \\
MG & 0.34 & 0.21 & 0.47 & $\mathbf{0 . 7 2}$ & 1.00 & & & & & & \\
CA & -0.36 & -0.22 & -0.54 & 0.46 & 0.26 & 1.00 & & & & & \\
pH & 0.5 & 0.33 & $\mathbf{0 . 7 5}$ & 0.23 & 0.53 & -0.29 & 1.00 & & & & \\
NA & 0.26 & 0.06 & 0.09 & $\mathbf{0 . 7 7}$ & $\mathbf{0 . 7 2}$ & 0.58 & 0.56 & 1.00 & & & \\
SA & -0.33 & -0.27 & -0.57 & -0.21 & -0.59 & 0.38 & -0.14 & 0.12 & 1.00 & & \\
SI & 0.57 & 0.67 & $\mathbf{0 . 8 7}$ & -0.15 & 0.44 & -0.58 & 0.39 & -0.17 & $\mathbf{- 0 . 8 4}$ & 1.00 & \\
CL & 0.22 & -0.44 & -0.24 & $\mathbf{0 . 7 7}$ & 0.29 & -0.05 & 0.16 & 0.34 & -0.15 & -0.2 & 1.00 \\
\hline
\end{tabular}

Table 4. Correlations matrix sediment parameters in monoculture (shrimp) and co-culture system (tilapia/shrimp) in all treatments during the dry season for 106 days. Correlations values in bold are significant at $P<0.05$. OM: organic matter, TN: organic nitrogen, TP: total phosphorus, K: potassium, Mg: magnesium, CA: calcium, pH: acidity, NA: sodium, SA: sand, SI: silt, CL: clay.

\begin{tabular}{lrrrrrrrrrrr}
\hline Variable & OM & \multicolumn{1}{c}{ TN } & \multicolumn{1}{c}{ TP } & \multicolumn{1}{c}{ K } & MG & CA & PH & NA & SA & SI & CL \\
\hline OM & 1.00 & & & & & & & & & & \\
TN & $\mathbf{0 . 7 7}$ & 1.00 & & & & & & & & & \\
TP & 0.53 & 0.64 & 1.00 & & & & & & & & \\
K & 0.22 & -0.23 & -0.15 & 1.00 & & & & & & & \\
MG & 0.34 & 0.21 & 0.47 & $\mathbf{0 . 7 2}$ & 1.00 & & & & & & \\
CA & -0.36 & -0.22 & -0.54 & 0.46 & 0.26 & 1.00 & & & & & \\
pH & 0.50 & 0.33 & $\mathbf{0 . 7 5}$ & 0.23 & 0.53 & -0.29 & 1.00 & & & & \\
NA & 0.43 & 0.51 & 0.78 & 0.17 & 0.65 & 0.00 & $\mathbf{0 . 8 9}$ & 1.00 & & & \\
SA & -0.33 & -0.27 & -0.57 & -0.21 & -0.59 & 0.38 & -0.14 & -0.16 & 1.00 & & \\
SI & 0.57 & 0.67 & $\mathbf{0 . 8 7}$ & -0.15 & 0.44 & -0.58 & 0.39 & 0.45 & $\mathbf{- 0 . 8 4}$ & 1.00 & \\
CL & 0.22 & -0.44 & -0.24 & $\mathbf{0 . 7 7}$ & 0.29 & -0.05 & 0.16 & -0.17 & -0.15 & -0.20 & 1.00 \\
\hline
\end{tabular}



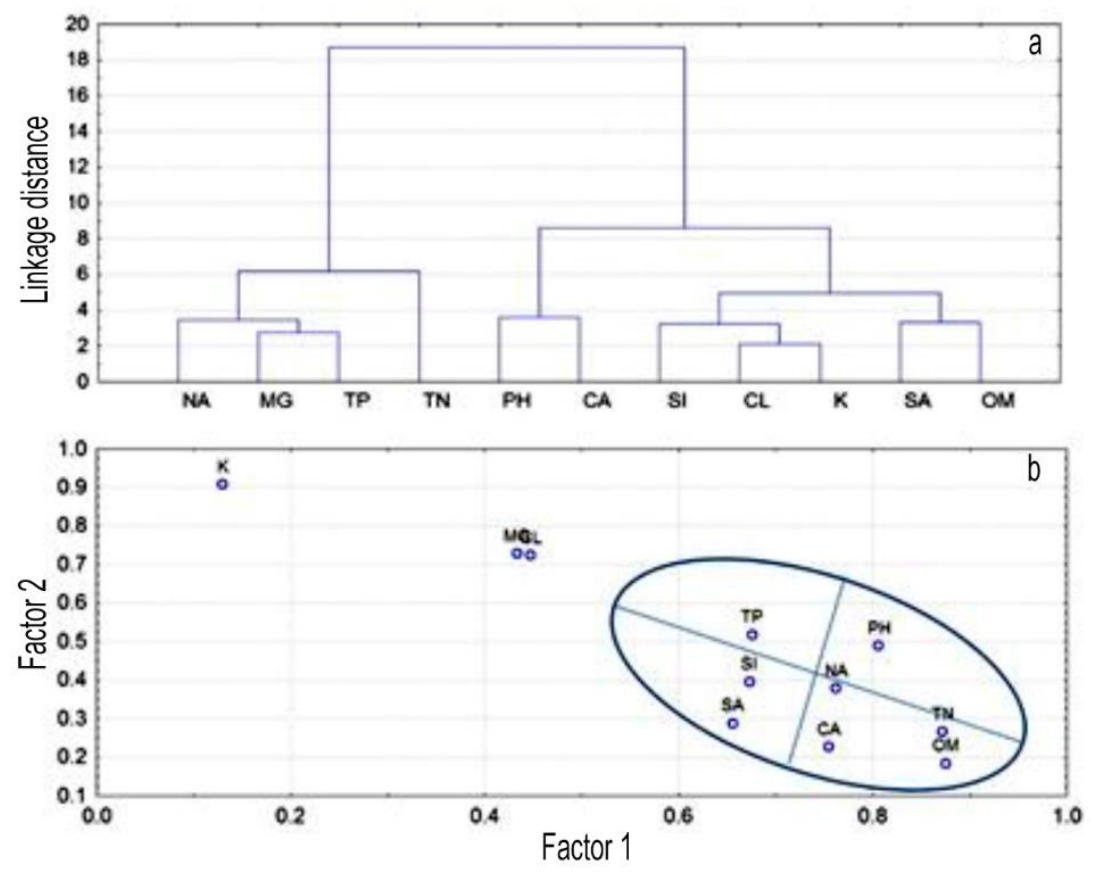

Figure 1. Sediment variables of monoculture (shrimp) and co-culture (tilapia/shrimp) of all treatments, during the two production cycles in the year. a) Dendrogram from hierarchical agglomerative cluster analysis, b) principal components analysis.

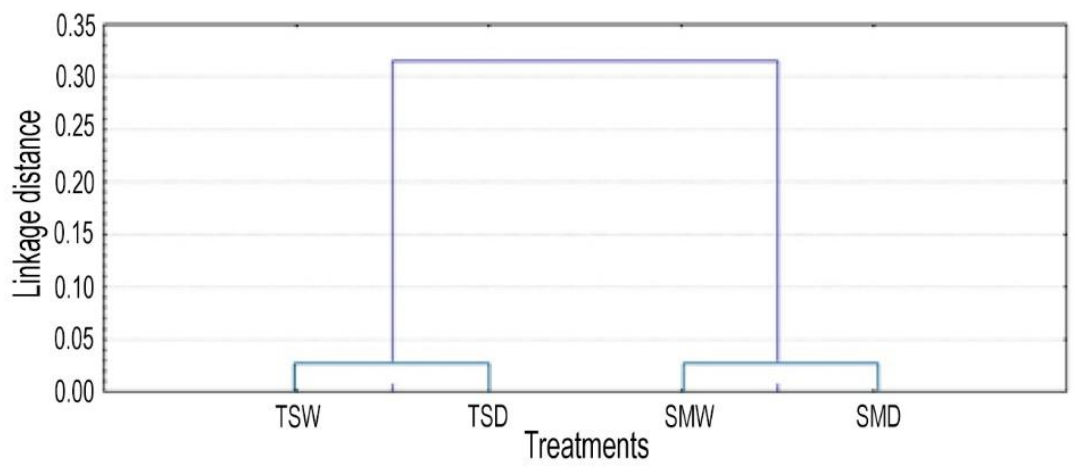

Figure 2. Sediment sampling stations of monoculture (shrimp Penaeus vannamei) and co-culture (tilapia Oreochromis niloticus-shrimp) of all treatments, during the rain and dry season. Dendrogram from hierarchical agglomerative cluster analysis.

the shrimp monoculture ponds and those of tilapiashrimp co-culture when forming the two groups (Fig. 2).

\section{DISCUSSION}

The main nutrients (TN, TP and $\mathrm{K}$ ), minor nutrients ( $\mathrm{Ca}, \mathrm{Mg}$ and $\mathrm{Na}$ ) and the texture (SA, SI and $\mathrm{CL}$ ) of the sediment at the bottom of white shrimp Penaeusvannamei monoculture and tilapia Oreochromis niloticus-shrimp co-culture were considered to deter-mine the effect of tilapia on the sediment of the shrimp ponds, because its trapping in the sediment of the ponds decreases the total productivity of the pond (Gul et al., 2015). Concerning the sediment texture of the ponds (higher proportion of silt and clay), the analysis showed that the ponds are more than 10 years old and are of the clay-loam type (Siddique et al., 2012). A high percen-tage of clay was found in the wet season due to the contribution of terrigenous material that drains the channel that supplies the water to the ponds. It showed a tendency in the dry season to increase the percentage of clay in co-culture due possibly to the effect of bioturbation caused by tilapia (Adámek \& Maršálek, 2013), although it is not significant. The $\mathrm{pH}$ registered in the 
ponds is close to that which is adequate for a good sediment production and in values that correspond to ponds with more than 10 years of operation (Siddique et al., 2012; Gul et al., 2015).

It was found that the concentration of major and minor nutrients in the sediment of shrimp ponds increased during the production cycle, a process reported by Ritvo et al. (1998). The concentration of OM found in the sediment of all the ponds was within what was reported for shrimp ponds in brackish water areas (Smith, 1996). A more considerable amount of organic matter was present in the sediment of the coculture due to the greater contribution of food and higher density of individuals concerning monoculture because the accumulation of sediments is mainly formed by exogenous contributions, eroded soil, uneaten food, feces, dead plankton and microorganisms (Hopkins et al., 1994). A high amount of TP was absorbed by the sediment of the monoculture ponds at the two seasons of the year, with more in the wet.

In general, the variations of nitrogen and phosphorus in the sediment of shrimp ponds were similar to those reported by Martin et al. (1998) and Perez-Osuna et al. (1999) in these culture systems with the same species. The more significant differences found between the concentrations of $\mathrm{TN}$ and $\mathrm{TP}$ in the sediment of the ponds in comparison with the other nutrients studied is due to the effect of the tilapia in the co-culture on the sediment mediate the bioturbation process as it has been described by Adámek \& Marsálek (2013). The present investigation corroborates that the effect of the tilapia, by the process of bioturbation of the sediment, affects the concentration of nitrogen and phosphorus. It increases the concentration of oxygen in the sediment (Brönmark \& Hansson, 2005), improving the process of mineralization (Hansen et al., 1998) of the culture pond contributing to better growth of the shrimp, as has been demonstrated in this work.

Potassium under culture conditions was supplied in ponds by fertilizer, balanced feed, tilapia, shrimp, water inflow and precipitation (Boyd et al., 2007). In the coculture, a higher concentration of $\mathrm{K}$ was recorded in the sediment compared to the initial, and there was a higher absorption in the co-culture sediment. However, harvesting and scraping after the production cycle decline significantly because it was removed through the discharged water, organisms and sediment removed from the pond (Boyd et al., 2007). $\mathrm{Mg}, \mathrm{Ca}$ and Na were related to the enrichment of the clays fraction because the smaller particles, particularly silts and clays, tend to adsorb and transport large amounts of nutrients due to their relatively larger specific surfaces. Also, it had a non-significant tendency to greater absorption of the co-culture sediment (Boyd et al., 1994).
In conclusion, in this experiment, tilapia was a factor that affected sediment quality, differences in growth between shrimp monoculture and tilapiashrimp co-culture can be explained, at least in part, by differences in their sediment.

\section{ACKNOWLEDGMENTS}

Juárez-Rosales thanks the Mexican National Council for Science and Technology (CONACYT) for the doctoral scholarship 626505 received during this research.

\section{REFERENCES}

Adámek, Z. \& Maršálek, B. 2013. Bioturbation of sediments by benthic macroinvertebrates and fish and its implication for pond ecosystems: a review. Aquaculture International, 21: 1-17.

Alam, M.J., Islam, M.L. \& Tuong, T.P. 2008. Introducing tilapia (GIFT) with shrimp (Penaeus monodon) in brackish water rice-shrimp system: impact on water quality and production. Bangladesh Journal of Fish Resources, 12(2): 187-195.

Aldama-Rojas, G., Ponce-Palafox, J.T., ArredondoFigueroa, J.L., Madrigal-Uribe, D., Luna, A.R., Ceja, E.S. \& Ramos, E.M. 2011. Morphological, sediment and soil chemical characteristics of dry tropical shallow reservoirs in the southern Mexican highlands. Journal of Limnology, 70(1): 139-144.

Avnimelech, Y., Kochva, M. \& Hargreaves, J.A. 1999. Sedimentation and resuspension in earthen fish ponds. Journal of the World Aquaculture Society, 30(4): 401409.

Bessa Jr., A.P., da Silveira, C.M., Silva-Thé Pontes, F. \& Henry-Silva, G.G. 2012. Polyculture of Nile tilapia and shrimp at different stocking densities. Revista Brasileira de Zootecnia, 41(7): 1561-1569.

Boyd, C.A., Boyd, C.E. \& Rouse, D.B. 2007. Potassium budget for inland, saline water shrimp ponds in Alabama. Aquacultural Engineering, 36: 45-50.

Boyd, C., Tannerm, M.E., Adkour, A. \& Asuda, K. 1994. Chemical characteristics of bottom soils from freshwater and brackish water aquaculture ponds. Journal of the World Aquaculture Society, 25(4): 517-533.

Brito, L.O., Simão-Pereira, B.R., Neto, J.B., Celicina, G.C. \& Borges, M.S. 2017. Plankton density in Litopenaeus vannamei and Oreochromis niloticus polyculture. Ciencia Animal Brasileira, 18: e16840.

Brönmark, C. \& Hansson, L.A. 2005. The biology of lakes and ponds. Oxford University Press, Oxford.

Candido, A.S., Melo Jr., A.P., Costa, O.R., Costa, H.J. \& Igarashi, M.A. 2005. Effect of different densities in feed conversion of tilapia Oreochromis niloticus with 
marine shrimp Litopenaeus vannamei in polyculture system. Revista Ciência Agrônomica, 36: 279-284.

Cheng, X., Zeng, Y., Guo, Z. \& Zhu, L. 2014. Diffusion of nitrogen $\&$ phosphorus across the sediment-water interface $\&$ in seawater at aquaculture areas of Dayabay, China. International Journal of Environmental Research \& Public Health, 11: 1557-1572.

Cruz, P.S., Andalecio, M.N., Bolivar, R.B. \& Fitzsimmons, K. 2008. Tilapia-shrimp polyculture in Negros Island, Philippines: a review. Journal of the World Aquaculture Society, 39: 713-725.

Dash, P., Avunje, S., Tandel, R.S. \& Panigrahi, A. 2017. Biocontrol of luminous vibriosis in shrimp aquaculture: a review of current approaches and future perspectives. Reviews in Fisheries Science \& Aquaculture, 25: 245-255.

Day, P.R. 1965. Hydrometer method of particle size analysis. In: Black, C.A. (Ed.). Methods of soil analysis. American Society of Agronomy, Madison, pp. 562-563.

Fan, L., Barry, K., Hu, G., Meng, S., Song, C., Qiu, L., Zheng, Y., Wu, W., Qu, J., Chen, J. \& Xu, P. 2017. Characterizing bacterial communities in tilapia pond surface sediment and their responses to pond differences and temporal variations. World Journal of Microbiology and Biotechnology, 33: 1-12.

Food and Agriculture Organization (FAO). 2013. Report of the FAO/MARD technical workshop on early mortality syndrome (EMS) or acute hepatopancreatic necrosis syndrome (AHPNS) of cultured shrimp (UNDER TCP/VIE/3304). Fisheries and Aquaculture Report, 1053: 54 pp., Hanoi, Vietnam, 25-27 June 2013.

Fitzsimmons, K.M. \& Shahkar, E. 2017. Tilapia-shrimp polyculture. In: Perschbacher, P.W. \& Stickney, R.R. (Eds.). Tilapia in intensive co-culture. John Wiley \& Sons, New Jersey, pp. 94-113.

García, E. 2004. Modificaciones al sistema de clasificación climática de Köppen. Serie Libros 6. Instituto de Geografía, Universidad Nacional Autónoma de México, Ciudad de México.

Gul, N., Mussaa, B., Masood, Z., Rehman, H., Ullah, A. \& Majeed, A. 2015. Study of some physiochemical properties of soil in fish pond at circuit house; district Sibi of province Balochistan, Pakistan. Global Veterinaria, 14: 362-365.

Hansen, K.S., Mouridsen, S. \& Kristensen, E. 1998. The impact of Chironomus plumosus larvae on organic matter decay and nutrient $(\mathrm{N}, \mathrm{P})$ exchange in shallow eutrophic lake sediment following phytoplankton sedimentation. Hydrobiologia, 364: 65-74.

Hernández-Barraza, C., Loredo, J., Adame, J. \& Fitzsimmons, K.M. 2012. Effect of Nile tilapia (Oreochromis niloticus) on the growth performance of
Pacific white shrimp (Litopenaeus vannamei) in a sequential polyculture system. Latin American Journal of Aquatic Research, 40: 936-942.

Hernández-Barraza, C., Cantú, D.L., Osti, J.L., Fitzsimmons, K. \& Nelson, S. 2013. Productivity of polycultured Nile tilapia (Oreochromis niloticus) and Pacific white shrimp (Litopenaeus vannamei) in a recirculating system. Israeli Journal of Aquaculture, 65: 5 .

Hopkins, J.S., Sandifer, P.A. \& Browdy, C.L. 1994. Sludge management in intensive pond culture of shrimp effect of management regime on water quality, sludge characteristics, nitrogen extinction, and shrimp production. Aquacultural Engineering, 13: 11-30.

Horwitz, W. (Ed.). 2002. Official methods of analysis of AOAC International. AOAC International. Maryland.

Jackson, M.L. 1973. Soil chemical analysis. Prentice-Hall, New Jersey.

Jatobá, A., do Nascimento-Vieira, F., Buglione-Neto, C.C., Mourino, J.L.P., Silva, B.C., Seiftter, W.Q. \& Andreatta, E.R. 2011. Diet supplemented with probiotic for Nile tilapia in polyculture system with marine shrimp. Fish Physiology and Biochemistry, 37: 725-732.

Joyni, M.J., Kurup, B.M. \& Avnimelech, Y. 2011. Bioturbation as a possible means for increasing production and improving pond soil characteristics in shrimp-fish brackish water ponds. Aquaculture, 318: 464-470.

López-Gómez, C., Ponce-Palafox, J.T., CastilloVargasmachuca, S., Puga-López, D., Castillo-Campo, L.F. \& García-Ulloa, M. 2017. Evaluation of two mixcultures of white shrimp (Litopenaeus vannamei) with red tilapia hybrid and spotted rose snapper (Lutjanus guttatus) in intensive indoor brackish water tanks. Latin American Journal of Aquatic Research, 45(5): 922-929.

Martin, J.L.M., Veran, Y., Guelorget, O. \& Pham, D. 1998. Shrimp rearing: stocking density, growth, impact on sediment, waste output, and their relationships studied through the nitrogen budget in rearing ponds. Aquaculture, 164: 135-149.

Milstein, A. \& Hernández, M. 2017. Ecological basis of tilapia co-culture ecological basis of tilapia co-culture systems. In: Perschbacher, P.W. \& Stickney, R.R. (Eds.). Tilapia in intensive co-culture. John Wiley \& Sons, New Jersey, pp. 1-24.

Muangkeow, B., Ikejima, K., Powtongsook, S. \& Yi, Y. 2007. Effects of white shrimp, Litopenaeus vannamei (Boone), and Nile tilapia, Oreochromis niloticus L., stocking density on growth, nutrient conversion rate, and economic return in integrated closed recirculation system. Aquaculture, 269: 363-376. 
Munsiri, P., Boyd, C.E. \& Hajek, B.F. 1995. Physical and chemical characteristics of bottom soil profiles in ponds at Auburn, Alabama, USA, and proposed method for describing pond soil horizons. Journal of the World Aquaculture Society, 26: 346-377.

Nimrat, S., Suksawat, S., Maleeweach, P. \& Vuthiphandchai, V. 2008. Effect of different shrimp pond bottom soil treatments on the change of physical characteristics and pathogenic bacteria in pond bottom soil. Aquaculture, 285: 123-129.

Omofunmi, O.E., Adewumi, J.K., Adisa, A.F. \& Alegbeleye, S.O. 2016. Development of a paddlewheel aerator for small and medium fish farmers in Nigeria. IOSR Journal of Mechanical and Civil Engineering, 13(1): 50-56.

Paez-Osuna, F., Guerrero-Galvan, S.R. \& Ruiz-Fernandez, A.C. 1999. Discharge of nutrients from shrimp farming to coastal waters of the Gulf of California. Marine Pollution Bulletin, 38: 585-592.

Ponce-Palafox, J.T., Ruiz-Luna, A., CastilloVargasmachuca, S., García-Ulloa, M. \& ArredondoFigueroa, J.L. 2011. Technical, economics and environmental analysis of semi-intensive shrimp (Litopenaeus vannamei) farming in Sonora, Sinaloa, and Nayarit states, on the east coast of the Gulf of California, Mexico. Ocean Coastal Management, 54: 507-513.

Ram, N.M., Zur, O. \& Avnimelech, Y. 1982. Microbial changes occurring at the sediment-water interface in an intensively stocked and fed fish pond. Aquaculture, 27: 63-72.

Rayment, G.E. \& Higginson, F.R. 1992. Australian laboratory handbook of soil and water chemical methods. Inkata Press, Melbourne.

Ritvo, G., Dixon, J.B., Lawrence, A.L., Neill, W.H. \& Speed, M.F. 1998. Accumulation of chemical elements in Texas shrimp pond soils. Journal of the World Aquaculture Society, 29: 422-431.

Rodríguez-Grimón, R.O. 2003. La tilapia y su efecto en la prevalencia del virus de la mancha blanca (WSSV) en poblaciones de camarón. Tesis de Maestría en Ciencias, Escuela Superior Politécnica del Litoral, Guayaquil, 72 pp.

Saraswathy, R., Muralidhar, M., Sanjoy, D., Kumararaja, P., Suvana, S., Lalitha, N., Katneni, V.K., Nagavel, A.N. \& Vijayan, K.K. 2019. Changes in soil and water quality at the sediment-water interface of Penaeus vannamei culture pond at varying salinities. Aquaculture Research, 50: 1096-1106.

Received: 15 May 2019; Accepted: 3 June 2019
Siddique, M.A.M., Barua, P. \& Ghani, M.H. 2012. Comparative study of physicochemical properties of soil according to the age of aquaculture pond of Bangladesh. Mesopotamian Journal of Marine Science, 27(1): 29-38.

Smith, P.T. 1996. Physical and chemical characteristics of sediments from prawn farms and mangrove habitats on the Clarence River, Australia. Aquaculture, 146: 4783.

Soil Survey Staff. 1999. Soil taxonomy: a basic system of soil classification for making and interpreting soil surveys. U.S. Department of Agriculture, Natural Resources Conservation Service. U.S. Government Printing Office, Washington.

Soil Survey Staff. 2014. Kellogg soil survey laboratory methods manual. In: Burt, R. \& Soil Survey Staff. (Eds.). Soil Survey Investigations Report 42. U.S. Department of Agriculture, Natural Resources Conservation Service, Nebraska.

Sokal, R.R. \& Rohlf, F.J. 2012. Biometry: the principles and practice of statistics in biological research. W.H. Freeman and Company, New York.

Sonnenholzner, S. \& Boyd, C. 2000. Chemical and physical properties of shrimp pond bottom soils in Ecuador. Journal of the World Aquaculture Society, 31: 358-375.

Sun, W., Dong, S., Jie, Z., Zhai, X., Zhang, H. \& Li, J. 2011. The impact of net-isolated polyculture of tilapia (Oreochromis niloticus) on plankton community in saline-alkaline pond of shrimp (Penaeus vannamei). Aquaculture International, 19: 779-788.

Tran, L., Fitzsimmons, K.M. \& Lightner, D.V. 2014. Tilapia could enhance water conditions; help control EMS in shrimp ponds. Global Aquaculture Advocate, 17: 11-12.

Van Duc, L., Song, B., Ito, H., Hama, T., Otani, M. \& Kawagoshi, Y. 2018. High growth potential and nitrogen removal performance of marine anammox bacteria in shrimp-aquaculture sediment. Chemosphere, 196: 69-77.

Wang, M. \& Lu, M. 2016. Tilapia polyculture: a global review. Aquaculture Resources, 47: 2363-2374.

Woerner, M. 1989. Métodos químicos para el análisis de suelos calizos de zonas áridas y semiáridas. Facultad de Ciencias Forestales, Universidad Autónoma de Nuevo León, Nuevo León.

Yang, P., Lai, D.Y.F., Yang, H., Tong, C., Lebel, L., Huang, J. \& Xu, J. 2019. Methane dynamics of aquaculture shrimp ponds in two subtropical estuaries, southeast China: dissolved concentration, net sediment release, and water oxidation. Journal of Geophysical Research: Biogeosciences, 124(6). doi: 10.1029/2018J G004794 